\title{
Estrogen Receptors in Immunohistochemically Stained Slides: Comparing Subjective and Computerized Evaluation Methods
}

\author{
Receptores de Estrógeno en Cortes Teñidos Inmunohistoquímicamente: \\ Comparación de Métodos de Evaluación Subjetivos y Computarizados
}

Ieda Millas*; Mirna Duarte Barros***; Daniella Franco Curcio ${ }^{* * *}$; Hudson Sousa Buck ${ }^{* * * * *}$ \& Bianca Maria Liquidato******

MILLAS, I.; BARROS, M. D.; CURCIO, D. F.; BUCK, H. S. \& LIQUIDATO, B. M. Estrogen receptors in immunohistochemically stained slides: comparing subjective and computerized evaluation methods. Int. J. Morphol., 32(4):1164-1170, 2014.

SUMMARY: Immunohistochemistry is a specific and sensitive staining method for detection of several proteins. One important function of this method is to help us on the diagnosis of the presence of specific receptors as the estrogen receptors. The aim of this study was to compare two different methods to evaluate immunohistochemical staining intensity to detect the presence of ER in the nasal mucosa tissue: one using a digital system and the other through conventional direct microscopy observation. Sixty two stained samples were observed and analyzed under optic microscopy by three specialized professionals, who have graded intensity from: absent, mild, moderate and intense staining. Afterwards, an objective measurement was obtained by a relative optical density (ROD) reading, through the MCID 7.0 system of densitometric digital analysis (Inter Focus Imaging LTDA, Linton, England). Subjective and objective classifications were compared under statistical analysis (Kolmogorov-Smirnov and Spearman Correlation Test, $\mathrm{p}<0.05$ ). We found a positive correlation between the subjective findings of observers and digital analysis in all the categories of beta receptor. For the alpha receptor, there was a correlation only in extreme categories. The subjective evaluations by observers and digital method by measuring the relative optical density show statistically significant correlations in quantifying the estrogen receptors by immunohistochemistry staining. This indicates that both methods show accuracy for the proposed study.

KEY WORDS: Immunohistochemistry; Estrogen receptors; Methods; Microscopy.

\section{INTRODUCTION}

Immunohistochemistry is a specific and sensitive staining method for detection of several proteins. This method has an important role in the detection of estrogen receptors, being useful in diagnosis of some kinds of hormone-dependent tumors, as breast cancer (Enmark \& Gustafsson, 1999; Green et al., 1986; Gokhale et al., 2007; Paech et al., 1997; Pavao \& Traish, 2001; Stierer et al., 1993; Zafrani et al., 2000).

Estrogen receptors (ER) are detectable in the human body tissues, including tissues of reproductive organs, nasal mucosa and nervous system (Ciocca \& Roig, 1995; Bowser \& Riederer, 2001; Berger et al., 2003; Kuiper et al., 1997; Millas et al., 2011; Philpott et al., 2004, 2008; Shirasaki et al., 2004; Toppozada et al., 1981, 1982, 1984, 1988). To evaluate staining intensity, different methods have been designed as RT-PCR and immunohistochemistry (Bowser \& Riederer; Pavao \& Traish; Shirasaki et al.; Zhao et al., 2001).

The immunohistochemistry method has been used to show whether or not there are some specific proteins. It's common to associate immunohistochemistry and another method, such as RT-PCR, to quantify the protein. But these two methods associated take more time to be done and the costs are higher (Aitken et al., 2010; Paech et al.; Zafrani et al.; Zhao et al.).

The development of different methods to evaluate staining intensity by immunohistochemistry have been performed. This is relevant because it is postulated that the darker the staining, the more receptors in the sample is

* Otolaryngologist, Instructor Professor Department of Morphology, Santa Casa de São Paulo School of Medical Sciences, SP, Brazil.

** Professor Chief, Department of Morphology, Santa Casa de São Paulo School of Medical Sciences, SP, Brazil.

*** Speech Terapist, Assistant Professor, Department of Morphology, Santa Casa de São Paulo School of Medical Sciences, SP, Brazil.

***** PHD, Professor Chief Department of Physiological Sciences, Santa Casa de São Paulo School of Medical Sciences, SP, Brazil.

******* Otolaryngologist, Assistant Professor, Department of Morphology, Santa Casa de São Paulo School of Medical Sciences, SP, Brazil. 
expected. So it would be possible to quantify and qualify the sample at the same time with lower cost (Gokhale at al.; Gustavson et al., 2009; Lejeune et al., 2008; Lopez et al., 2008; Matos et al., 2006).

The method that has frequently been used is the double or triple blind evaluation of the staining intensity by optic microscopy (Berger et al.; Matos et al.; Stierer et al.; Zafrani et al.; Millas et al., 2010). This method usually analyses the samples as absent staining; mild staining; moderate staining and intense positive staining from the immunohistochemical reaction. However, this method is also subjective.

Digital media, colorimetric counts, cell counts, measures of specific areas in histological sections, among others are objective methods for evaluating staining intensity by immunohistochemistry (Aitken et al.; Gokhale et al.; Gustavson et al.; Lejeune et al.; Lopes et al.; Matos et al.; Zafrani et al.).

The objective of this study was to compare two different methods to evaluate immunohistochemical staining intensity to detect the presence of ER in the nasal mucosa tissue: one using a digital system and the other through conventional direct microscopy observation.

\section{MATERIAL AND METHOD}

The current study was prospectively designed and approved by the Ethics Committee for Human Research from "Irmandade da Santa Casa de Misericórdia de São Paulo" and it was carried out in accordance with the ethical standards of the aforementioned institution. Signed consent forms were obtained from all patients.

For this prospective study, 62 samples of the inferior turbinate mucosa were collected from female patients undergoing nasal surgery due to septum deviation. Samples of the inferior nasal turbinate were collected with turbinectomy scissors without previous infiltration. These samples were immersed in $10 \%$ formaldehyde to be embedded in paraffin and underwent immunohistochemical staining for detection of alpha and beta ER.

To investigate alpha and beta ERs, the paraffin blocks were submitted to the standard methodology for immunohistochemistry in accordance with previous descriptions. Primary antibodies against ER were applied. Alpha estrogen receptors were detected with mouse antihuman ERa antibodies 1D5 clone, code M7047. Beta estrogen receptors were detected with mouse anti-human ERb antibodies PPG5/10 clone, code M7292 (Dako, Carpinteria-CA, USA). The positive controls for alpha and beta ER were obtained from breast carcinoma tissue, and these underwent analysis simultaneously with the nasal tissue under study. Both controls showed dark-brown granular staining in the cellular compartment where the antigenprimary antibody binding had occurred. The analysis was developed at the Laboratory Department of Morphology of the Santa Casa School of Medical Sciences, São Paulo.

The slices from the inferior turbinate mucosa were analyzed by means of optical microscopy and were randomly photographed. Each case was analyzed for the presence of dark brown granular areas and similarity with the matched positive controls, as well as for its distribution in the nucleus of respiratory epithelium cells and in the cytoplasm and nucleus of the glandular epithelium cells. The immunohistochemical analysis was performed by three observers (OBS), who were unaware of the patient's sex, age or background.

The assessment of immunohistochemical patterns was also conducted semi-quantitatively according to staining intensity, which consisted of four classifications: absent, mild, moderate and intense (Fig. 1).

Afterwards, an objective measurement was obtained by a relative optical density (ROD) reading, through the MCID 7.0 system of densitometric digital analysis (Inter Focus Imaging LTDA, Linton, England). Slices were digitally photographed using a calibration system previously standardized for each picture in size and illumination intensity. A monochromatic scale was used in shades of black and gray, where the darker the color, the higher the immunohistochemical staining, and therefore, the higher the concentration of ER. With this method, it was not possible to distinguish cellular areas, such as cytoplasm and nucleus. Thus, six different respiratory epithelium areas and six different glandular areas of lamina propria of each picture were randomly selected (Fig. 2). Numeric data were then obtained, according to the staining intensity, and submitted for statistical analysis, consistent with the average values between the six analyzed areas of each slide. The calibration attributed the value of $0.15 \mathrm{ROD}$ to the lighter area and 0.70 to the darker.

To meet the objectives of the study ROD measures were described according to OBS classification for each alpha and beta receptor. Kolmogorov-Smirnov tests were conducted (Kirkwood \& Sterne, 2006) to ascertain the normal distribution of ROD values in each OBS category, with no escape from this assumption ( $p>0.05$ ). ROD values were 


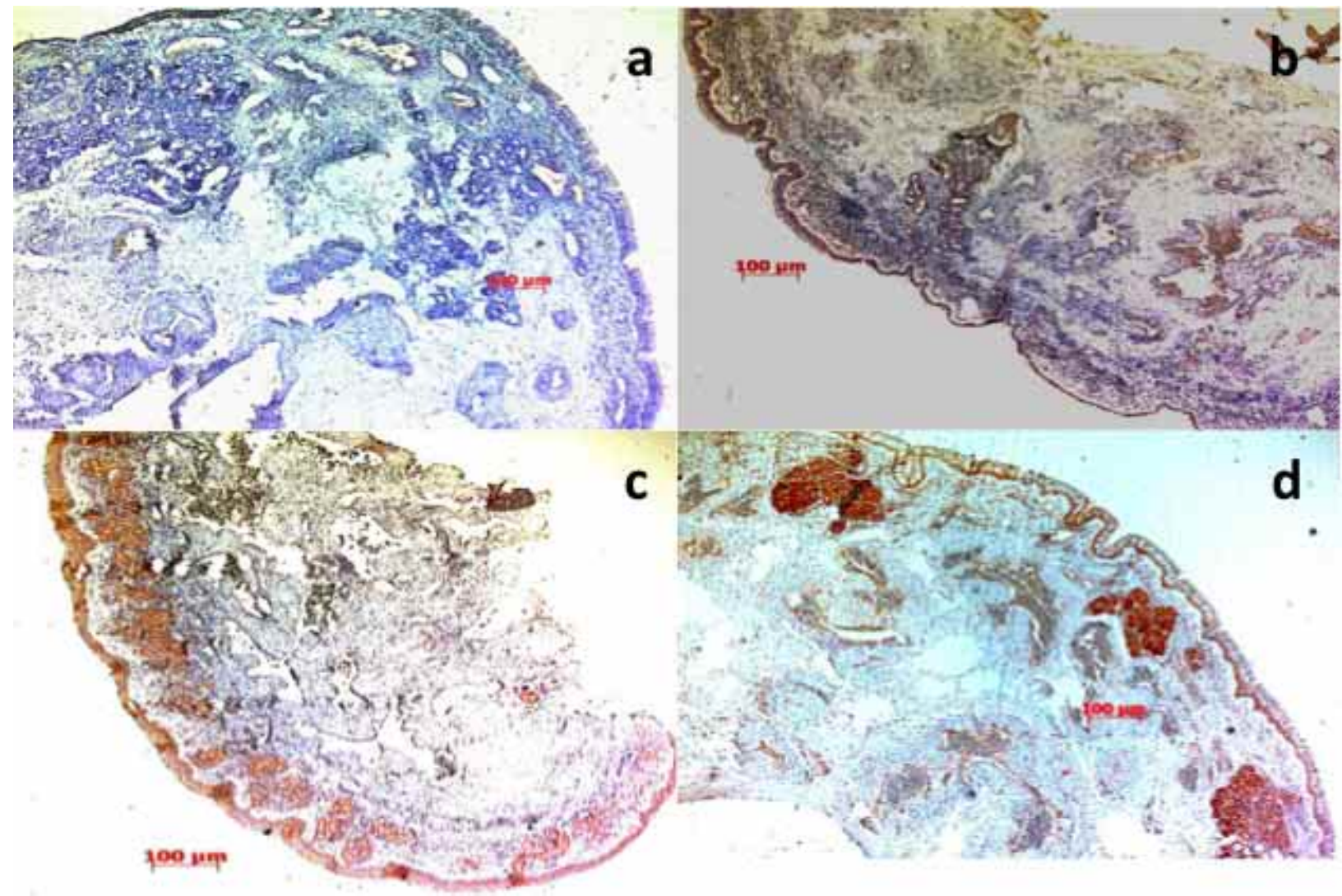

Fig. 1. Immunohistochemical staining intensity for estrogen receptor in optical microscopy (50X) in the respiratory epithelium and glandular epithelium of lamina propria of nasal inferior turbinate: a- absent; b-mild; c-moderate; d-intense.

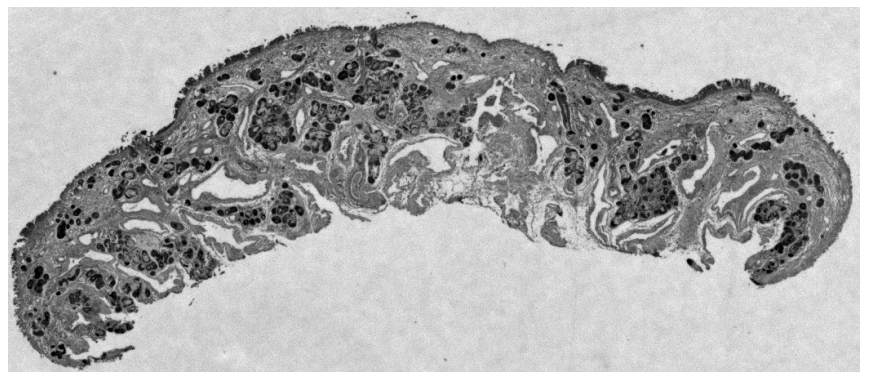

Fig. 2. Picture of inferior turbinate mucosa with immunohistochemical staining for estrogen receptor in monochromatic scale (50X).

compared between OBS categories for each receptor using ANOVA (Neter et al., 1996) followed by Tukey's multiple comparisons (Neter et al.) to compare the ROD values of between each two categories.

The tests were performed at a significance level of 5\%. Spearman correlations were calculated in order to assess the correlation between OBS and ROD for each receptor (Kirkwood \& Sterne). The tests were performed at a significance level of $5 \%$.

\section{RESULTS}

The average of the ROD values for alpha receptor observed were as follows, according to the categories of OBS: absent 0.18 ; mild 0.25 , moderate 0.30 and intense 0.34 . The average of ROD values for beta receptor observed were as follows, according to the OBS categories: mild 0.25, moderate 0.29 and intense 0.36 (Figs. 3 and 4, Table I). Figures 3 and 4 suggest increased values of ROD as OBS intensity increase for each receptor.

Table I shows that for both receptors Alpha and Beta, the ROD values have on average statistically significant differences between the categories of OBS $(\mathrm{p}<0.05)$.

Comparing consecutive and non-consecutive categories, we found that for alpha receptor there is an average increase of ROD statistically significant between nonconsecutive categories of OBS intensity $(\mathrm{p}<0.05)$, but this did not occur between consecutive categories. To the Beta receptor, there is an average increase of ROD statistically significant for all categories of OBS $(\mathrm{p}<0.05)$ (Table II). 


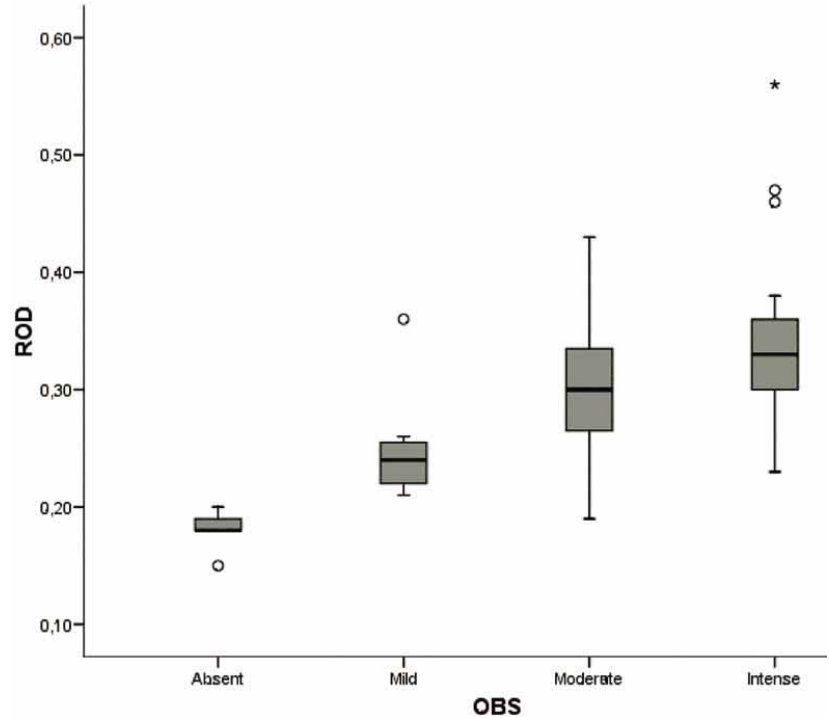

Fig. 3. Boxplot of ROD x OBS for Alpha receptor. ROD: Relative Optical Density; OBS: Observer evaluation of the staining method; Absent, Mild, Moderate and Intense, respectively: no, mild, moderate and intense immunohistochemistry staining observed in optical microscopy.

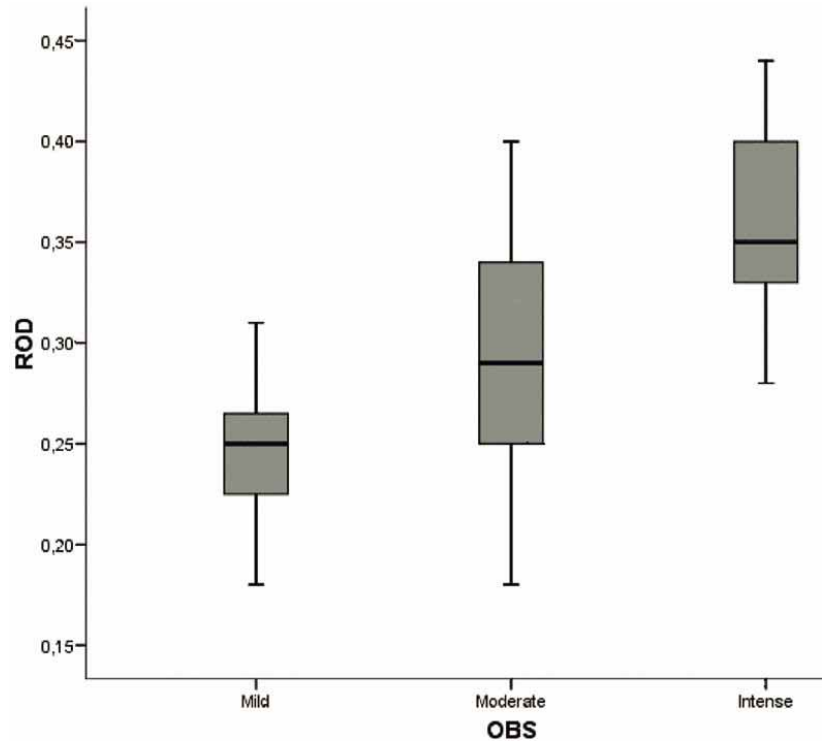

Fig. 4. Boxplot of ROD x OBS for Beta receptor. ROD: Relative Optical Density; OBS: Observer evaluation of the staining method; Mild, Moderate and Intense, respectively: mild, moderate and intense immunohistochemistry staining observed in optical microscopy.

Table I. Description of ROD according to OBS categories for each receptor and the result of comparative tests.

\begin{tabular}{llccccccc}
\hline Receptor & OBS & Average & SD & Median & Minimum & Maximum & n & p \\
\hline \multirow{4}{*}{ Alpha } & Absent & 0.18 & 0.02 & 0.18 & 0.15 & 0.2 & 5 & \\
& Mild & 0.25 & 0.05 & 0.24 & 0.21 & 0.36 & 7 & $<\mathbf{0 . 0 0 1}$ \\
& Moderate & 0.30 & 0.06 & 0.3 & 0.19 & 0.43 & 28 & \\
\multirow{3}{*}{ Beta } & Intense & 0.34 & 0.07 & 0.33 & 0.23 & 0.56 & 22 & \\
& Mild & 0.25 & 0.04 & 0.25 & 0.18 & 0.31 & 12 & \\
& Moderate & 0.29 & 0.06 & 0.29 & 0.18 & 0.4 & 29 & $<\mathbf{0 . 0 0 1}$ \\
& Intense & 0.36 & 0.05 & 0.35 & 0.28 & 0.44 & 21 & \\
\hline
\end{tabular}

A correlation between OBS and ROD was verified for each receptor. In both receptors OBS and ROD show direct correlation statistically significant ( $\mathrm{p}<0.05)$, namely, the higher the intensity the larger OBS it is ROD for each receptor, alpha and beta (Table III).
Table III. Results of Spearman correlations between OBS and ROD for each receptor.

\begin{tabular}{lccc}
\hline Receptor & Correlation & n & p \\
\hline Alpha & 0.557 & 62 & $<\mathbf{0 . 0 0 1}$ \\
Beta & 0.643 & 62 & $<\mathbf{0 . 0 0 1}$ \\
\hline
\end{tabular}

Table II. Results of multiple Comparisons of ROD among OBS categories for each receptor.

\begin{tabular}{|c|c|c|c|c|c|c|c|}
\hline \multirow{2}{*}{ Receptor } & \multirow{2}{*}{\multicolumn{2}{|c|}{ Comparison }} & \multirow{2}{*}{$\begin{array}{l}\text { Average } \\
\text { difference }\end{array}$} & \multirow{2}{*}{$\begin{array}{c}\text { Standard } \\
\text { error }\end{array}$} & \multirow{2}{*}{$\mathbf{p}$} & \multicolumn{2}{|c|}{ CI $(95 \%)$} \\
\hline & & & & & & Inferior & Superior \\
\hline \multirow{5}{*}{ Alpha } & Absent & Mild & -0.071 & 0.038 & 0.250 & -0.172 & 0.029 \\
\hline & Absent & Moderate & -0.124 & 0.032 & 0.001 & -0.208 & -0.040 \\
\hline & Absent & Intense & -0.164 & 0.032 & $<0.001$ & -0.249 & -0.078 \\
\hline & Mild & Moderate & -0.053 & 0.028 & 0.236 & -0.125 & 0.020 \\
\hline & Mild & Intense & -0.092 & 0.028 & 0.010 & -0.167 & -0.018 \\
\hline \multirow{4}{*}{ Beta } & Moderate & Intense & -0.040 & 0.019 & 0.152 & -0.089 & 0.009 \\
\hline & Mild & Moderate & -0.047 & 0.017 & 0.022 & -0.088 & -0.006 \\
\hline & Mild & Intense & -0.112 & 0.018 & $<0.001$ & -0.155 & -0.068 \\
\hline & Moderate & Intense & -0.065 & 0.014 & $<0.001$ & -0.099 & -0.030 \\
\hline
\end{tabular}




\section{DISCUSSION}

The evaluation of estrogen receptors by immunohistochemistry method is well known because it has a high degree of sensitivity and specificity. On the other hand, it is not widely used as a quantitative method, in other words, in order to estimate the concentration of these receptors, especially due to the lack of numerical data.

Estrogen produces numerous physiological effects in both men and women that include neuroendocrine actions, actions in the reproductive tract and in lipid, mineral, protein and carbohydrate metabolism (Ciocca \& Roig; Enmark \& Gustafsson; Pavao \& Traish). So, the activity of this hormone extends beyond its primary function associated with reproduction.

The relationship between the hormone estrogen and the nasal mucosa has been postulated by clinical studies that advocate the existence of an entity named hormonal rhinitis, or nasal diseases caused by variations in the hormone levels, especially estrogen, and according to the work of Philpott et al. (2004, 2008), Shirasaki et al. (2004); Toppozada et al. (1981, 1982, 1984, 1988) and Zhao et al. (2001).

As quoted by Kuiper et al., the majority of the actions of estrogen are performed through their respective receptors in various organs and tissues.

It is claimed that the higher the concentration of estrogen receptors, the higher its expression, indicating that the analyzed tissue may be more responsive to the hormone and thus perform specific protein synthesis that will determine changes in the patterns of cellular metabolism (Aitken et al.; Gustavson et al.; Lejeune et al.; Matos et al.).

There are several methods used for quantification of immunohistochemistry markers, that have been pursued with the aim of reducing costs and runtime, which avoids adding another laboratory method, besides the advantage of quantifying specific areas of interest in the histological section. In general, an appropriate methodology requires high levels of sensitivity, accuracy, reproducibility and standardization. Thus, several authors have suggested methods for quantitative analysis of immunohistochemical staining with digital media, colorimetric counts, cell counts, measures of specific areas in histological sections, among others (Aitken et al.; Gokhale et al.; Gustavson et al.; Lejeune et al.; Lopes et al.; Matos et al.; Zafrani et al.).

A wide variety of techniques described show the lack of a consensus or the difficulty in obtaining a method having the above mentioned ideal characteristics.

This way, this study provides one more option that may be suitable for other staining techniques that we want to identify and quantify specific proteins, e.g, in our case, estrogen receptors.

The quantification of receptors for right viewing of staining intensity by a specialist has been used in many cases, but may show a high level of failures due to subjectivity of this evaluation. Furthermore, to obtain the accuracy of results requires observation by more than an experienced observer, which makes this procedure more complex.

In our study, we found a positive correlation between the subjective findings of observers and digital analysis in all the categories of beta receptor, which is the receptor that is more easily expressed and stained nasal mucosa (Millas et al.; Shirasaki et al.). For the alpha receptor, there was a correlation only in extreme categories, as between light and intense, and not the ones between moderate-light and moderate-intense. This is explained because in the nasal mucosa, the alpha receptor is more weakly stained in relation to the beta, complicating the interpretation by the examiners as the digital reading.

Importantly, there was a correlation between the direct visualization of the staining intensity by the observer and the digital analysis of relative optical density in both receptors. This indicates that both methods are acceptable and reliable, since they show similar results.

So this is another technique available at low cost and easy procedure that can be adapted for other procedures and contribute to other studies when one wants to locate and quantify certain colorimetric markers in histological sections.

The subjective evaluations by observers and digital method by measuring the relative optical density show statistically significant correlations in quantifying the estrogen receptors by immunohistochemistry staining. This indicates that both methods show accuracy for the proposed study.

\section{ACKNOWLEDGMENTS}

This study has been supported by FAP (Fundo de Amparo à Pesquisa) of Santa Casa School of Medical Sciences, São Paulo and CNPq (National Council of Technological and Scientific Development). 
MILLAS, I.; BARROS, M. D.; CURCIO, D. F.; BUCK, H. S. \& LIQUIDATO, B. M. Estrogen receptors in immunohistochemically stained slides: comparing subjective and computerized evaluation methods. Int. J. Morphol., 32(4):1164-1170, 2014.

MILLAS, I.; BARROS, M. D.; CURCIO, D. F.; BUCK, H. S. \& LIQUIDATO, B. M. Receptores de estrógeno en cortes teñidos inmunohistoquímicamente: comparación de métodos de evaluación subjetivos y computarizados.Int. J. Morphol., 32(4):1164-1170, 2014.

RESUMEN: La inmunohistoquímica es un método de tinción específico para la detección de varias proteínas. Este método es importante en el diagnóstico de la presencia de receptores específicos, tales como los receptores de estrógeno. El objetivo de este estudio fue comparar dos métodos diferentes para evaluar la intensidad de la tinción inmunohistoquímica para detectar la presencia de RE en el tejido de la mucosa nasal: el primero utilizando un sistema digital y el segundo a través de la observación directa de microscopía convencional. Tres profesionales especializados observaron sesenta y dos muestras teñidas las que fueron analizadas con microscopio óptico con la siguiente intensidad de tinción: ausente, leve, moderada e intensa. Posteriormente, se obtuvo una medición objetiva a través de lectura de densidad óptica relativa (DOR) del sistema MCID 7.0 de análisis de densitometría digital (Inter Enfoque de imágenes LTDA, Linton, Inglaterra). Clasificaciones subjetivas y objetivas fueron comparadas bajo análisis estadístico (Kolmogorov-Smirnov y prueba de correlación de Spearman, p<0,05). Encontramos una correlación positiva entre los resultados subjetivos de los observadores y el análisis digital en todas las categorías de los receptores beta. Para el receptor alfa, hubo una correlación solamente en categorías extremas. Las evaluaciones subjetivas de los observadores y método digital midiendo la densidad óptica relativa muestran correlaciones estadísticamente significativas en la cuantificación de los receptores de estrógeno por tinción inmunohistoquímica. Por tanto ambos métodos demostraron ser correctos para el estudio propuesto.

PALABRAS CLAVE: Inmunohistoquímica; Receptores de estrógeno; Métodos; Microscopía.

\section{REFERENCES}

Aitken, S. J.; Thomas, J. S.; Langdon, S. P.; Harrison, D. J. \& Faratian, D. Quantitative analysis of changes in ER, PR and HER2 expression in primary breast cancer and paired nodal metastases. Ann. Oncol., 21(6):1254-61, 2010 .

Berger, G.; Balum-Azim, M. \& Ophir, D. The normal inferior turbinate: histomorphometric analysis and clinical implications. Laryngoscope, 113(7):1192-8, 2003.

Bowser, C. \& Riederer, A. Detection of progesterone receptors in connective tissue cells of the lower nasal turbinates in women. Laryngorhinootologie, 80(4):1826, 2001 .

Ciocca, D. R. \& Roig, L. M. V. Estrogen Receptors in Human Nontarget Tissues: Biological and Clinical Implications. Endocr. Rev., 16(1):35-62, 1995.

Enmark, E. \& Gustafsson, J. A. Oestrogen receptors an overview. J. Intern. Med., 246(2):133-8, 1999.

Gokhale, S.; Rosen, D.; Sneige, N.; Diaz, L. K.; Resetkova, E.; Sahin, A.; Liu, J. \& Albarracin, C. T. Assessment of two automated imaging systems in evaluating estrogen receptor status in breast carcinoma. Appl. Immunohistochem. Mol. Morphol., 15(4):451-5, 2007.

Green, S.; Walter, P.; Kumar, V.; Krust, A.; Bornert, J. M.; Argos, P. \& Chambon, P. Human estrogen receptor
cDNA: sequence, expression and homology to v-erb-A. Nature, 320(6058):134-9, 1986.

Gustavson, M. D.; Bourke-Martin, B.; Reilly, D. M.; Cregger, M.; Williams, C.; Tedeschi, G.; Pinard, R. \& Christiansen, J. Development of an unsupervised pixelbased clustering algorithm for compartmentalization of immunohistochemical expression using Automated Quantitative Analysis. Appl. Immunohistochem. Mol. Morphol., 17(4):329-37, 2009.

Kirkwood, B. R. \& Sterne, J. A. C. Essential medical statistics. $2^{\text {nd }}$ ed. Massachusetts, Blackwell Science, 2006. p.502.

Kuiper, G. G.; Carlsson, B.; Grandien, K.; Enmark, E.; Haggblad, J.; Nilsson, S. \& Gustafsson, J. A. Comparison of the ligand binding specificity and transcript tissue distribution of estrogen receptors alpha and beta. Endocrinology, 138(3):863-70, 1997.

Lejeune, M.; Jaen, J.; Pons, L.; López, C.; Salvadó, M. T.; Bosh, R.; García, M.; Escriva, P.; Boucells, J.; Cugat, X. \& Alvaro, T. Quantification of diverse subcellular immunohistochemical markers with clinicobiological relevancies: validation of a new computer-assisted image analysis procedure. J. Anat., 212(6):868-78, 2008.

Lopez, C.; Lejeune, M.; Escriva, P.; Bosch, R.; Salvadó, M. T.; Pons, L. E.; Baucells, J.; Cugat, X.; Alvaro, T. \& 
MILLAS, I.; BARROS, M. D.; CURCIO, D. F.; BUCK, H. S. \& LIQUIDATO, B. M. Estrogen receptors in immunohistochemically stained slides: comparing subjective and computerized evaluation methods. Int. J. Morphol., 32(4):1164-1170, 2014.

Jaen, J. Effects of image compression on automatic count of immunohistochemical stained nuclei in digital images. J. Am. Med. Inform. Assoc., 15(6):794-8, 2008.

Matos, L. L.; Stabenow, E.; Tavares, M. R.; Ferraz, A. R.; Capelozzi, V. L. \& Pinhal, M. A. Immunohistochemistry quantification by a digital computer-assisted method compared to semiquantitative analysis. Clinics (São Paulo), 61(5):417-24, 2006.

Millas, I.; Liquidato, B. M.; Dolci, J. E. L.; Macea, J. R.; Fregnani, J. H. T. G. \& Meceles, L. R. Inmunohistochemical evaluation of estrogen receptors alpha and beta in normal inferior turbinate mucosa. Int. J. Morphol., 28(1):143-50, 2010.

Millas, I.; Liquidato, B. M.; Buck, H. S.; Barros, M. D.; Paes, R. A. \& Dolci, J. E. Evaluation of estrogenic receptors in the nasal mucosa of women taking oral contraceptives. Contraception, 83(6):571-7, 2011.

Neter, J.; Kutner, M. H.; Nachtsheim, C. J. \& Wasserman, W. Applied Linear Statistical Models. $4^{\text {th }}$ ed. Ilinois, Richard D. Irwing, 1996. p.1408.

Paech, K.; Webb, P.; Kuiper, G. G.; Nilsson, S.; Gustafsson, J.; Kushner, P. J. \& Scanlan, T. S. Differential ligand activation of estrogen receptors ERalpha and ERbeta at AP1 sites. Science, 277(5331):1508-10, 1997.

Pavao, M. \& Traish, A. M. Estrogen receptor antibodies: specificity and utility in detection, localization and analyses of estrogen receptor alpha and beta. Steroids, 66(1):1-16, 2001.

Philpott, C. M.; El-Alami, M. \& Murty, G. E. The effect of the steroid sex hormones on the nasal airway during the normal menstrual cycle. Clin. Otolaryngol. Allied Sci., 29(2):138-42, 2004.

Philpott, C. M.; Wild, D. C.; Wolstensholme, C. R. \& Murty, G. E. The presence of ovarian hormone receptors in the nasal mucosa and their relationship to nasal symptoms. Rhinology, 46(3):221-5, 2008.

Shirasaki, H.; Watanabe, K.; Kanaizumi, E.; Konno, N.; Sato, J.; Narita, S. \& Himi, T. Expression and localization of steroid receptors in human nasal mucosa. Acta Otolaryngol., 124(8):958-63, 2004.

Stierer, M.; Rosen, H.; Weber, R.; Hanak, H.; Spona, J. \& Tuchler, H. Immunohistochemical and biochemical measurement of estrogen and progesterone receptors in primary breast cancer. Correlation of histopathology and prognostic factors. Ann. Surg., 218(1):13-21, 1993.

Toppozada, H.; Michaels, L.; Toppozada, M.; El-Ghazzawi, E.; Talaat, A. \& Elwany, S. The human nasal mucosa in the menstrual cycle. J. Laryngol. Otol., 95(12):1237-47, 1981.

Toppozada, H.; Michaels, L.; Toppozada, M.; El-Ghazzawi, I.; Talaat, M. \& Elwany, S. The human respiratory nasal mucosa in pregnancy. An electron microscopic and histochemical study. J. Laryngol. Otol., 96(7):613-26, 1982.

Toppozada, H.; Toppozada, M.; El-Ghazzawi, I. \& Elwany, $\mathrm{S}$. The human respiratory nasal mucosa in females using contraceptive pills. An ultramicroscopic and histochemical study. J. Laryngol. Otol., 98(1):43-51, 1984.

Toppozada, H. The human nasal mucosa in the menopause (a histochemical and electron microscopic study). J. Laryngol. Otol., 102(4):314-8, 1988.

Zafrani, B.; Aubriot, M. H.; Mouret, E.; De Crémoux, P.; De Rycke, Y.; Nicolas, A.; Boudou, E.; Vincent-Salomon, A.; Magdelénat, H. \& Sastre-Garau, X. High sensitivity and specificity of immunohistochemistry for the detection of hormone receptors in breast carcinoma: comparison with biochemical determination in a prospective study of 793 cases. Histopathology, 37(6):536-45, 2000.

Zhao, X. J.; McKerr, G.; Dong, Z.; Higgins, C. A.; Carson, J.; Yang, Z. Q. \& Hannigan, B. M. Expression of oestrogen and progesterone receptors by mast cells alone, but not lymphocytes, macrophages or other immune cells in human upper airways. Thorax, 56(3):205-11, 2001.

\author{
Correspondence to: \\ leda Millas \\ Rua Diogo de Faria, 1087 /1104 \\ São Paulo-SP \\ BRAZIL
}

Email: iedamillas@uol.com.br; ieda.orl@gmail.com

Received: 13-09-2013

Accepted: 23-12-2013 